\title{
KAKO SU SE SNA ŠLI KLUBOVI ČITATELJA SUOČENI S PANDEMIJOM BOLESTI COVID-19?
}

\author{
HOW DID BOOK CLUBS \\ FACE THE COVID-19 PANDEMIC?
}

Žozefina Žentil-Barić
Gradska knjižnica Zadar
zbaric@gmail.com
Nada Radman
Gradska knjižnica Zadar
nada.radman5@gmail.com

UDK / UDC: [028:061.2:027.022]:616.2-

044.372(497.4)(497.5)

Izvorni znanstveni rad / Original scientific paper

Primljeno / Received: 26. 6. 2021.

Prihvaćeno /Accepted: 24. 10. 2021.

\section{Sažetak}

Cilj. Cilj istraživanja bio je utvrditi u kojoj je mjeri i kako pandemija bolesti COVID-19 utjecala na klubove čitatelja.

Metodologija. Istraživanje je provedeno anketnim upitnikom na daljinu od 10. studenog do 7. prosinca 2020. godine. Istovremeno je provedeno među narodnim knjižnicama u Republici Hrvatskoj i Republici Sloveniji. Usmjereno je na klubove čitatelja koji su djelovali tijekom 2019. i 2020. godine, razdoblju koje je uključivalo vrijeme neposredno prije i tijekom pandemije.

Rezultati. U Hrvatskoj su od 62 aktivna kluba čitatelja prije pandemije, njih 33 (53\%) nastavilo s radom tijekom pandemije, a u Sloveniji je od početnih 47 klubova s radom nastavilo njih 19 (40\%). Dio klubova brzo se prilagodio novim okolnostima i nastavio $\mathrm{s}$ radom $\mathrm{u}$ virtualnom prostoru ili kombinirajući komunikaciju i susrete na daljinu sa susretima uživo kad je to bilo moguće. Kod primjene alata informacijsko-komunikacijske tehnologije u objema su se zemljama dogodili identični procesi koji pokazuju 
da su se klubovi čitatelja pri suočavanju s pandemijom više usredotočili na održavanje kontakta s postojećim članovima nego na promociju klubova i privlačenje novih članova. Kod dijela klubova pandemija je prouzročila potpuni prekid rada: u Hrvatskoj 47 \%, u Sloveniji $38 \%$ anketiranih klubova.

Društveni značaj. U širem smislu rad doprinosi ukupnoj slici o prilagodbi kulturnog sektora na pandemijske uvjete i o novim zahtjevima koji su preda nj postavljeni za ostvarenje komunikacije s publikom. U radu je utvrđen utjecaj pandemije na ubrzanje procesa primjene novih tehnologija za internetsku komunikaciju.

Originalnost/vrijednost. Rad nudi usporednu analizu utjecaja pandemije na kontinuitet rada čitateljskih klubova u Hrvatskoj i Sloveniji te načina njihove prilagodbe novim okolnostima. Temelji se na dosad neobjavljenim rezultatima istraživanja o radu čitateljskih klubova tijekom pandemije s posebnim naglaskom na upotrebu alata informacijsko-komunikacijske tehnologije (IKT) kao mogućih pomagala za prevladavanje ograničenja koja su u sklopu protuepidemijskih mjera propisana za susrete uživo.

Ključne riječi: COVID-19, digitalni alati, istraživanje, klub čitatelja, narodne knjižnice

\section{Abstract}

Aim. The research goal was to determine to what extent and in what way book clubs were affected by the COVID-19 disease pandemic.

Methodology. The paper presents results of an online questionnaire survey conducted from November 10 to December 7, 2020. The research was conducted simultaneously in public libraries in the Republic of Croatia and the Republic of Slovenia. It was aimed at book clubs that were active during 2019 and 2020, as a period that included the time immediately before and during the COVID-19 pandemic.

Results. In Croatia, out of 62 active book clubs before the pandemic, 33 (53\%) continued to operate during the pandemic. In Slovenia, out of the initial 47 clubs, 19 (40\%) continued with their activities. These clubs quickly adapted to the new circumstances and continued to work in the virtual space or by combining online communication and remote meetings with live meetings whenever possible. Regarding the application of the Information Communication Technology (ICT) tools, the identical processes have taken place in both countries: book clubs were more focused on maintaining contact with the existing members than on promoting clubs and attracting new members. However, the pandemic caused the complete termination of activities for some book clubs: in Croatia $47 \%$, in Slovenia $38 \%$ of the surveyed clubs.

Social significance. The paper contributes to the overall picture of the adaptation of the cultural sector to pandemic conditions and complying with the new requirements in order to communicate with its public. The paper identifies the impact of the pandemic on accelerating the process of applying new technologies for Internet communication. 
Originality/value. The paper offers a comparative analysis of the impact of the pandemic on the continuity of book clubs' activities in Croatia and Slovenia and how they have adapted to new circumstances. It is based on the hitherto unpublished research results on book club activities during the pandemic, with special emphasis on the use of ICT tools as possible aids to overcome the restrictions prescribed for live meetings as part of anti-epidemic measures.

Keywords: book club, COVID-19, ICT tools, public libraries, research

\section{Uvod}

Klubovi čitatelja osnivaju se u neformalnim i institucijskim okruženjima, sastaju se uživo i online, okupljaju pojedince različitih dobnih i interesnih skupina, stoljećima povezuju ljude u različitim prilikama. Tijekom 2020. godine posebne izazove postavila im je pandemija bolesti COVID-19. Početkom godine ta akutna virusna bolest zahvatila je sve kontinente, pa je Svjetska zdravstvena organizacija (WHO) u ožujku proglasila pandemiju bolesti COVID-19. ${ }^{1}$ U Hrvatskoj je epidemija proglašena 11. ožujka², a u Sloveniji 12. ožujka 2020. godine ${ }^{3}$ odlukama nacionalnih ministara zdravstva. Uvedene su stroge epidemiološke mjere, što je značajno promijenilo svakodnevno funkcioniranje svih segmenata društva, pa tako i narodnih knjižnica.

Jedna je od važnijih uloga narodne knjižnice zadovoljavanje potrebe pojedinca za osobnim razvojem i svrhovitim provođenjem slobodnog vremena. ${ }^{4}$ Program kojim se učinkovito ostvaruje navedena uloga jest čitateljski klub ili grupa ${ }^{5}-$ zajednica individualnih čitatelja koje povezuje ljubav prema čitanju i argumentiranoj raspravi. Prijašnja istraživanja provođena u Hrvatskoj pokazala su da značajan broj narodnih knjižnica ima klubove čitatelja namijenjene različitim dobnim i interesnim skupinama. ${ }^{6}$

1 COVID-19 bolest. // Hrvatska enciklopedija. Mrežno izd. Leksikografski zavod Miroslav Krleža. [citirano 2021-01-20]. Dostupno na: http://www.enciklopedija.hr/Natuknica.aspx?ID=70912.

2 Odluka o proglašenju epidemije bolesti COVID-19 uzrokovane virusom SARS-Cov-2 na području čitave Republike Hrvatske. // Ministarstvo zdravstva Republike Hrvatske, 2020. [citirano 2020-12-20]. Dostupno na: https://zdravlje.gov.hr/koronavirus-i-mjere-prevencije/4952.

3 Slovenija razglasila epidemijo novega koronavirusa. // Republika Slovenija: GOV.SI, 2020. [citirano 2021-08-31]. Dostupno na: https://www.gov.si/novice/2020-03-12-slovenija-razglasila-epidemijo-novega-koronavirusa.

4 IFLA-ine smjernice za narodne knjižnice. / uredile C. Koontz i B. Gubbin. Zagreb: Hrvatsko knjižničarsko društvo, 2011. Str. 15-21.

5 Za razlikovanje termina vidi: Bašić, I. O čitateljskim grupama: Metodički priručnik s primjerima dobre prakse. Zagreb: Balans centar za logopedagogiju i biblioterapiju, 2014. Str. 38-39.

6 Usp. Bokan, A.; D. Cupar. Promocija i promicanje čitanja u narodnim knjižnicama Republike Hrvatske. // Libellarium 10, 1(2017), str. 51-76. DOI: http://dx.doi.org/10.15291/libellarium.v1i1.290.; Duić, M.; M. Anđić. Čitateljski klubovi u narodnim knjižnicama velikih hrvatskih gradova. // Vjesnik bibliotekara Hrvatske 62, 2(2019), str. 89-111. DOI: https://doi.org/10.30754/vbh.62.2.764. 
Klubovi čitatelja društveno su i institucijski prepoznati oblici djelovanja na području poticanja aktivnoga kritičkog čitanja, pa nisu samo knjižničarima zanimljivi. Udruga Hrvatsko čitateljsko društvo koja okuplja pravne i fizičke osobe različitih struka zainteresirane za promicanje, istraživanje i unapređivanje čitanja i pismenosti u društvu održala je 2014. godine stručni skup pod nazivom „Čitateljski klubovi i grupe u Hrvatskoj“. Tim se skupom htjelo istaknuti dobrobit tog jednostavnog načina rada koji smanjuje izolaciju u zajednici omogućujući ljudima sličnih interesa dublje i smislenije povezivanje u male čitateljske zajednice. ${ }^{7}$ Hrvatsko čitateljsko društvo tada je iskazalo namjeru da na svojim mrežnim stranicama kreira i vodi bazu čitateljskih grupa/klubova osnovanih na području Republike Hrvatske kako bi se zainteresiranima osiguralo dovoljno informacija o načinu osnivanja i radu klubova uključujući podatke o tome gdje se i kako mogu pridružiti nekom od postojećih klubova. ${ }^{8}$ Po malom broju predstavljenih klubova čitatelja zaključuje se da ideja još uvijek nije u potpunosti zaživjela. Sličan pokušaj u Sloveniji na sebe je preuzeo portal Dobreknjige.si namijenjen promicanju čitanja. Portal povezuje slovenske narodne knjižnice, a aktivan je i u povezivanju književnih kritičara, društava, izdavača i drugih aktera na polju knjige, pa ne iznenađuje interes i za kreiranje podstranice za klubove čitatelja. ${ }^{9} \mathrm{~S}$ obzirom na to da ni njihova podstranica nije zaživjela kako su htjeli, tijekom 2020. godine napravili su nadogradnju na temelju povratnih informacija dobivenih od moderatora klubova čitatelja. Urednici portala ističu da im je želja uspostaviti „popis“ svih oblika čitateljskih skupina kako bi njihova stranica svima zainteresiranima mogla biti ulazna točka u svijet čitateljskih klubova i izvor korisnih informacija o njihovu sastajanju, o tome što čitaju i kako im se pridružiti.

\subsection{Zašto su и kontekstu pandemije zanimljivi klubovi čitatelja?}

Narodne su knjižnice mjesta susreta, razmjene ideja, interakcije korisnika s knjižničarima, ali i drugim korisnicima - mjesta socijalizacije i komunikacije. Upravo to članovima pruža i klub čitatelja kao jedan od prisutnijih knjižničnih programa za poticanje čitanja i konstruktivno provođenje slobodnog vremena. I upravo to otežava pandemija bolesti COVID-19 s nužnim epidemiološkim mjerama poput zatvaranja knjižnica, smanjenja broja korisnika koji u isto vrijeme mogu biti prisutni u prostoru, držanja fizičke distance, nošenja zaštitnih maski u zatvorenom prostoru i tako dalje, budeći u ljudima osjećaje straha, neizvjesnosti,

\footnotetext{
7 Perković, I. Stručni skup: Čitateljski klubovi i grupe u Hrvatskoj. // Moderna vremena info: e-zine \& portal za knjigu i kulturu čitanja, 2014. [citirano 2020-12-20]. Dostupno na: https:// mvinfo.hr/clanak/strucni-skup-citateljski-klubovi-i-grupe-u-hrvatskoj.

8 Baza čitateljskih klubova. // Hrvatsko čitateljsko društvo. [citirano 2020-12-20]. Dostupno na: http://hcd.hr/registracija-citateljski-klubova.

9 Medved, K. Bralni klubi na portalu Dobreknjige.si. // Bukla: Brezplačna revija o dobrih knjigah 16, 157(2020), str. 50. [citirano 2020-12-23]. Dostupno na: http://www.bukla.si.; https:// issuu.com/revijabukla/docs/bukla-157.
} 
distanciranosti i otuđenosti. ${ }^{10}$ Strah i neizvjesnost normalna su reakcija na pojavu nove zarazne bolesti o kojoj se ne zna mnogo. ${ }^{11}$

Posljedice pandemije nisu samo vezane za zdravlje i zdravstveni sustav, nego su izražene i brige zbog narušene kvalitete života, ekonomske brige te zabrinutost za obiteljske odnose i dostupnost socijalne podrške. ${ }^{12}$ Takve stresne uvjete života može ublažiti osjećaj pripadnosti grupi ljudi koja dijeli interese i aktivnosti, čiji su članovi spremni pomoći jedni drugima pružajući međusobnu podršku i poštovanje putem ohrabrenja, slaganja s idejama i osjećajima sugovornika, informacijske i emocionalne podrške, ali i izravne pomoći u materijalnim dobrima i uslugama (npr. obavljanje kupovine namirnica za osobe u samoizolaciji). ${ }^{13}$ Takva grupa može biti i klub čitatelja. Nakon višemjesečnoga redovitog sastajanja članovi kluba uglavnom postaju prijateljska skupina koja često na temelju razmjene doživljaja o pročitanom tekstu proširi razgovor na dijeljenje životnih iskustava. Pomnim odabirom knjige za čitanje i razgovorom punim međusobnog poštovanja i empatije, klub ima potencijal antistresnoga i terapeutskog djelovanja na članove. Ivana Bašić ističe da razgovor o pročitanoj knjizi u klubu čitatelja zadovoljava neke važne komunikacijske potrebe suvremenog čovjeka i stvara osjećaj povezanosti s drugim ljudima. ${ }^{14}$ Prema DeNel Rehberg Sedo sami članovi klubova često vjeruju kako se popularnost klubova čitatelja krije u tome da ljudi žele ponovno imati osjećaj pripadnosti nekoj zajednici te da je razmjena ideja u razgovoru o knjigama jedan od načina da to postignu..$^{15}$ U Sloveniji su to već iskusili krajem 90 -ih godina 20. st. i početkom 21. stoljeća tijekom djelovanja kluba čitatelja „Beremo z Manco Košir" u sklopu kojega se sastajalo oko 30 čitateljskih grupa diljem zemlje. ${ }^{16}$

10 Vidi Bubić, A. Kako se nositi sa situacijom prouzrokovanom pandemijom koronavirusne bolesti (COVID-19)? Zagreb: Naklada Slap, 2020.Str. 8. [citirano 2021-01-15] Dostupno na: http://www.nakladaslap.com/public/docs/knjige/ostanidoma-covid-19.pdf.

11 Muslić, Lj. Koronavirus kao prijetnja mentalnom zdravlju. // Koronavirus i mentalno zdravlje: Psihološki aspekti, savjeti i preporuke. / uredila A. Bogdan i suradnici. Zagreb: Hrvatska psihološka komora, 2020. Str. 14. [citirano 2020-12-20]. Dostupno na:

http://psiholoska-komora.hr/static/documents/HPK-Koronavirus_i_mentalno_zdravlje.pdf.

12 Begić, D.; A. Lauri Korajlija; N. Jokić Begić. Psihičko zdravlje liječnika u Hrvatskoj za vrijeme pandemije COVID-19. // Liječnički vjesnik 142, 7/8(2020), str. 196. [citirano 2020-12-20]. Dostupno na: https://hrcak.srce.hr/243213.

13 Milić Babić, M. Socijalna podrška i roditeljstvo. // Socijalne teme: Časopis za pitanja socijalnog rada i srodnih znanosti 1, 6(2019), str. 15-16. [citirano: 2021-01-21].

Dostupno na: https://hrcak.srce.hr/233278.

14 Bašić, I. Nav. dj., str. 10-11.; 27.

15 Rebergh Sedo, D. Readers in reading groups: An Online survey of face-to-face and virtual book clubs. // Convergence: The International Journal of Research into New Media Technologies 9, 1(2003), str. 85. [citirano: 2021-01-10]. Dostupno na: https://www.researchgate.net/publication/249828932 Readers_in_Reading_GroupsAn_Online_Survey_of_Face-to-Face_and_Virtual_Book_Clubs.

16 Kavčič, P. Intervju z Manco Košir: Dobre knjige nas berejo. // Knjižnica. Revija za področje bibliotekarstva in informacijske znanosti 61, 4(2017), str. 10. [citirano: 2020-12-23]. Dostupno na: https://ojs-gr.zrc-sazu.si/knjiznica/article/view/6726. 
Prema Košir, druženje i razgovor o knjigama sudionicima donijeli su povezujuću energiju i puno života - žene su se u manjim sredinama češće dotjerivale, bile su radosnije i aktivnije, što je utjecalo i na opću atmosferu u tim sredinama. Tvrdnja Mance Košir iz 2017. godine da bi nam danas tako nešto trebalo još više nego prije jer smo još više otuđeni, prestrašeni i nesigurni, upravo u jeku pandemije bolesti COVID-19 dodatno naglašava važnost klubova čitatelja.

Istraživanja su pokazala da u vrijeme pandemije ljudi pokazuju više razine stresa u odnosu na podatke prije pandemije. ${ }^{17} \mathrm{U}$ takvim kriznim situacijama izuzetno je važno međusobno povezivanje ljudi i davanje podrške, u čemu može pomoći suvremena tehnologija koja omogućuje redovitu komunikaciju s dragim osobama uz uvažavanje epidemioloških mjera. ${ }^{18}$ Uvažavanje preporuka epidemiologa o smanjenim izravnim kontaktima i fizičkoj distanci te život u karanteni usmjerili su ljude da u virtualnom svijetu zadovolje potrebu za osjećajem povezanosti s drugima. ${ }^{19} \mathrm{Tu}$ potrebu svojih korisnika knjižnice mogu pokušati zadovoljiti nastavljanjem susreta klubova čitatelja u virtualnom prostoru. Poznato je kako sudionici klubova koji imaju čvrstu bazu redovitih članova tijekom višegodišnjih sastanaka dijele povijest i razvijaju određeni stupanj intimnosti, ${ }^{20}$ pa bi nastavak susreta mogao tim ljudima ublažiti stres omogućivši im da se sastaju s dragim osobama s kojima dijele interese: ljubav prema knjigama i čitanju, dijeljenje dojmova i raspravljanje o pročitanom štivu.

Promijenjeni uvjeti poslovanja uzrokovani protuepidemijskim mjerama potaknuli su razne kulturne institucije, pa tako i narodne knjižnice, na intenzivniju prisutnost $\mathrm{u}$ virtualnom prostoru. Kako bi ostale povezane sa svojom publikom, suočile su se s izazovom i prilagodile situaciji pribjegavši digitalnim kanalima i platformama kao novoj podlozi za sigurnu socijalnu interakciju inspiriranu kulturnim sadržajima. ${ }^{21}$ Knjižničari su ponukani na upoznavanje širokog raspona alata informacijsko-komunikacijske tehnologije (IKT alata) i korištenje njima. Mnogi od tih alata predstavljeni su u dodatku hrvatskom izdanju Smjernica za knjižnične usluge za mladež 2009. godine, u kojima je prepoznato da upravo klubovi čitatelja

17 Begić, D.; A. Lauri Korajlija; N. Jokić Begić. Nav. dj., str. 196.

18 Muslić, Lj. Nav. dj., str. 16.

19 Jokić Begić, N. Više će zbog psihoze koja se stvorila stradati psihičko zdravlje nego tjelesno. // Koronavirus i mentalno zdravlje: Psihološki aspekti, savjeti i preporuke. / uredila A. Bogdan i suradnici. Zagreb: Hrvatska psihološka komora, 2020. Str. 17.

20 Gruzd, A.; D. Rehberg Sedo. \#1b1t: Investigating reading practices at the turn of the twenty-first century. // Mémoires du livre. Studies in Book Culture 3, 2(2012), str. 1-25. DOI: https:// doi.org/10.7202/1009347ar.

${ }_{21}$ Montalto, V.; P. L. Sacco; V. Alberti; F. Panela; M. Saisana. European cultural and creative cities in COVID-19 times. // European Commission, JRC Science for Policy Report. Jobs at risk and the policy response. Luxembourg: Publications Office of the European Union, 2020. Str. 6. [citirano: 2021-03-20]. Dostupno na: https://ec.europa.eu/jrc/en/publication/eur-scientific-and-technical-research-reports/european-cultural-and-creative-cities-covid-19-times. 
mogu kvalitetno iskoristiti virtualan prostor kao podršku vlastitim klupskim aktivnostima, ali i za spajanje s drugim klubovima diljem svijeta. ${ }^{22} \mathrm{U}$ međuvremenu su se razvile nove generacije alata među kojima su za rad kluba čitatelja vrlo zanimljivi servisi i aplikacije za besplatne grupne videopozive: Zoom, Google Meet, Google Duo, Microsoft Teams itd. Ti suvremeni komunikacijski alati sredstvo su za održavanje susreta više ljudi u virtualnom prostoru u realnom vremenu, čime i nastavak redovitog sastajanja članova kluba čitatelja tijekom epidemije postaje moguć. Izvedivost takvih susreta ovisi o posjedovanju odgovarajuće opreme i internetske veze, ali i o sposobnosti snalaženja pojedinca sa suvremenom tehnologijom. I za knjižničare i za članove kluba to može biti veći izazov i zahtjevnije od susreta uživo zato što je tako teže uspostaviti kontakt sa sugovornicima i zato što nedostaje dio neverbalne komunikacije. ${ }^{23}$ Iako je pri videopozivu manje ograničenja nego pri komunikaciji telefonom te $e$-poštom ili chatom, s obzirom na to da sugovornike i čujemo i vidimo, ipak je komunikacija reducirana i ograničena ${ }^{24}$, što predstavlja veći izazov za održavanje kvalitetnog susreta, posebno voditelju kluba čitatelja. Osim toga, digitalni sadržaji ne mogu se smatrati savršenom zamjenom za iskustvo uživo jer su lokalni prostori i fizički susreti ono što povezuje i osnažuje zajednicu. ${ }^{25}$

Virtualni klubovi čitatelja nisu novost. U literaturi se mogu pronaći analize različitih odlika virtualnih klubova među kojima se ističu one vezane uz slobodu koju pruža internet: nisu ograničeni na određeno mjesto i vrijeme susreta jer su dostupni 24/7, pa komentirati može svatko kada odgovara, nisu ograničeni ni na krug članova jedne knjižnice ili lokalne zajednice, pa mogu učiniti iskorak prema daleko široj publici, a kreirani sadržaji i nakon gašenja kluba korisnicima interneta mogu služiti kao inspiracija i zanimljiv izvor informacija/preporuka za čitanje. ${ }^{26}$ Ovdje treba skrenuti pozornost na to da se u stručnoj literaturi, koja je autorima ovog članka bila dostupna, kod opisivanja virtualnih klubova radilo o klubovima koji ne ovise o susretu u realnom vremenu jer je riječ o susretima kroz e-poštu ili komentare na blogovima i društvenim mrežama koji su zainteresiranim sudionici-

22 Smjernice za knjižnične usluge za mladež: Prerađeno izdanje Smjernica koje je 1996. objavio Stalni odbor Sekcije knjižnica za djecu i mladež. / priređivači P. Muller, I. Chew, A. Jurinović i K. Zauder. Web 2.0 i knjižnične usluge za mladež: Uvod za knjižničare. / priredio I. Chew. Zagreb: Hrvatsko knjižničarsko društvo, 2009. Str. 48.

23 Vračić, I. Psihološka prva pomoć u krizi. // Koronavirus i mentalno zdravlje: Psihološki aspekti, savjeti i preporuke. Nav. dj., str. 29.

24 Isto.

25 Montalto, V.; P. L. Sacco; V. Alberti; F. Panela; M. Saisana. Nav. dj., str. 6.

26 Vidi npr. Kolarić, A.; S. Šimić; V. Štivić; Ž. Žentil Barić. Čitateljski blogovi Tragači i Knjiški frikovi: Usluge za djecu i mlade na Web-u 2.0. // Vjesnik bibliotekara Hrvatske 56, 3(2013), str. 91-100. Dostupno i na: https://www.hkdrustvo.hr/vjesnik-bibliotekara-hrvatske/index.php/vbh/ article/view/164/159.; vidjeti i: Lima, C. Reader's interactions in an online reading group. // Language and Literacy 19, 4(2017), str. 129-142. DOI: https://doi.org/10.20360/G21D4F.; Gruzd, A.; D. Rehberg Sedo. Nav. dj. 
ma dostupni u bilo koje doba dana i noći. Danas je razvoj komunikacijske tehnologije omogućio da se uporabom interneta susreti klubova čitatelja mogu održavati u realnom vremenu videopozivom, čime se postiže dojam sličan sastanku uživo, ali se pritom gube gotovo sve spomenute prednosti virtualnog kluba. Iako je u obama slučajevima riječ o virtualnom klubu čitatelja, razlike među njima upućuju na potrebu diferencijacije pojma. Za potrebe ovog rada nije se ulazilo u distinkciju pojmova, nego se pojmom virtualni susret obuhvaćaju oba načina uporabe suvremene tehnologije za održavanje susreta klubova čitatelja na internetu.

Primjer uspješnoga hrvatskog virtualnog kluba jest „Čitateljski klub Knjižnice I. B. Mažuranić" (Knjižnice grada Zagreba) osnovan 2013. godine na društvenoj mreži Facebook u obliku javne grupe. Prvotno je zamišljen kao svojevrsni produžetak postojećeg kluba čitatelja, kao mjesto za komunikaciju članova tog kluba, ali i za njihovo informiranje o događanjima u knjižnici. Ubrzo se za članstvo u grupi prijavljuju zaljubljenici u čitanje iz čitave Hrvatske i šire regije, a kvalitetnim osvrtima na knjige i komentarima privlači brojne pisce i izdavačke kuće s kojima se uspostavlja intenzivna suradnja. ${ }^{27}$ Trenutno okuplja oko 1200 članova ${ }^{28} \mathrm{i}$ mada rasprave o objavljenim osvrtima na knjige više nisu brojne i intenzivne kao na početku, još uvijek je vrlo aktivan i predstavlja kvalitetan izvor čitateljima u potrazi za inspiracijom za čitanje.

S obzirom na to da su specifični uvjeti rada uzrokovani pandemijom bolesti COVID-19 značajno utjecali na programsku ponudu narodnih knjižnica, zanimalo nas je kako su se klubovi čitatelja snašli u novonastalim okolnostima, odnosno jesu li nastavili s radom ili su obustavili sve klupske aktivnosti. U tu svrhu provedeno je istraživanje kojem je $u$ fokusu uporaba IKT alata za održavanje kontinuiteta rada klubova, a pritom se nije bavilo sadržajnim obilježjima klubova čitatelja, odnosno područjem književnih interesa, motivacijom članstva za sudjelovanje i sl.

\section{Opis istraživanja}

U početku se planiralo provesti istraživanje samo u Republici Hrvatskoj, ali je utvrđeno da će se zanimljiviji pregled dobiti usporedbom podataka u odgovarajućem međunarodnom kontekstu. Odlučeno je istraživanjem obuhvatiti narodne knjižnice u susjednoj Republici Sloveniji kao zemlji s kojom Hrvatska dijeli brojne sličnosti, kao što su društveno-povijesno nasljeđe, članstvo u Europskoj uniji i usporedivi sustavi narodnih knjižnica. Kvalitetna suradnja koju narodne knjižnice međusobno ostvaruju olakšala je distribuciju anketnih upitnika i provedbu istraživanja.

27 Kelava, I.; M. Šimić. Čitateljski klubovi knjižnice Ivane Brlić Mažuranić u stvarnom i virtualnom svijetu. // Hrčak: Glasilo hrvatskog čitateljskog društva, 48/49(2014), str. 6. [citirano: 2020-12-21]. Dostupno na: https://issuu.com/hrcak_hcd/docs/48_49_12_2014.

28 Čitateljski klub Knjižnice I. B. Mažuranić. Facebook grupa. [citirano: 2021-01-15]. Dostupno na: https://www.facebook.com/groups/144815659013627. 


\subsection{Cilj i hipoteza}

Cilj istraživanja bio je utvrditi u kojoj je mjeri i kako aktualna pandemija utjecala na klubove čitatelja. Postavljena je hipoteza da je pandemija bolesti COVID-19 uzrokovala prestanak rada klubova čitatelja u hrvatskim i slovenskim narodnim knjižnicama.

\subsection{Metodologija}

Istraživanje je provedeno online od 10. studenoga do 7. prosinca 2020. godine. Za istraživačku metodu odabrana je anketa kako bi se u kratkom razdoblju mogao obuhvatiti što veći uzorak. U skladu s postavljenim ciljem, istraživanje je usmjereno na klubove čitatelja koji su djelovali tijekom 2019. i 2020. godine, razdoblju koje je uključivalo vrijeme neposredno prije i tijekom pandemije. U središtu istraživanja bili su klubovi čitatelja, ali s obzirom na to da na državnim razinama ne postoje službene evidencije aktivnih klubova, za uzorak su odabrane narodne knjižnice: 208 hrvatskih ${ }^{29}$ i 58 slovenskih knjižnica. ${ }^{30}$ Kako bi se dobio što bolji uvid u zastupljenost klubova čitatelja, istraživanjem se htjelo obuhvatiti sve narodne knjižnice u Hrvatskoj i Sloveniji, bilo da još nemaju čitateljski klub, bilo da su u posljednje dvije godine imale klubove čitatelja s dugom tradicijom ili su ih tek osnovale. Istraživanje je obuhvatilo virtualne i fizičke klubove. $\mathrm{Na}$ temelju literature i iskustva iz prakse odlučeno je da se za potrebe istraživanja terminom klub čitatelja koristi u smislu jedne skupine čitatelja koja se redovito sastaje kako bi se razgovaralo o pročitanome.

Instrument istraživanja bio je anketni upitnik izrađen u aplikaciji Google obrasci, pa je za njegovo ispunjavanje bio potreban internetski pristup. Anketa je koncipirana tako da se za svaki klub čitatelja zasebno ispuni upitnik te da ih popunjavaju voditelji klubova ili knjižničari koji su neposredno zaduženi za određeni klub. Pripremljen je jedan upitnik na hrvatskom jeziku, a drugi, identičan, na slovenskom jeziku. Upitnik je podijeljen na sedam segmenata: Opis istraživanja, Uvodne informacije, Osnovne informacije o klubu čitatelja, Djelovanje kluba u razdoblju prije COVID-19 pandemije, Rad kluba za vrijeme pandemije, Prestanak rada kluba, Možda je osnovan klub tijekom pandemije. Svi ispitanici imali su pristup informacijama i pitanjima u prvim trima segmentima, a zatim su odgovarali samo na one segmente koji su bili relevantni za situaciju u njihovu klubu. Pitanja

29 Statistički podaci i pokazatelji uspješnosti za narodne knjižnice za 2019. godinu. // Portal matične djelatnosti knjižnica u Republici Hrvatskoj, 2019. [citirano: 2020-12-28]. Dostupno na: http://maticna.nsk.hr/statistika/preuzimanje.

30 Koordinacija osrednjih območnih knjižnic (OOK). // Narodna in univerzitetna knjižnica Slovenia. [citirano: 2020-12-28]. Dostupno na: https://www.nuk.uni-lj.si/nuk/ook; Slovenske splošne knjižnice. // Portal slovenskih splošnih knjižnic. [citirano: 2020-12-28]. Dostupno na: https:// www.knjiznice.si. 
su bila otvorenog tipa za slobodno odgovaranje vlastitim riječima ili zatvorenog tipa s ponuđenim odgovorima, ali uvijek s mogućnošću dopune u slučaju da među predloženim odgovorima nema odgovarajućeg izbora. Anketni upitnik distribuiran je putem mreže matičnih knjižnica u Hrvatskoj te posredstvom koordinatorice središnjih regionalnih knjižnica u Sloveniji.

Zbog opsežnosti prikupljenih podataka, u radu su predstavljeni samo rezultati istraživanja koji su u najužoj vezi s postavljenom hipotezom i ciljem istraživanja.

\subsection{Rezultati}

\subsubsection{Uvodne informacije}

U istraživanju su sudjelovale 54 narodne knjižnice iz Republike Hrvatske $(26 \% \text { uzorka })^{31}$ sa 79 ispravno popunjenih upitnika i 31 narodna knjižnica iz Republike Slovenije (53 \% uzorka) s 39 ispravno popunjenih upitnika. U Hrvatskoj je odgovorilo 16 od 20 županijskih matičnih narodnih knjižnica, a u Sloveniji 8 od 10 središnjih regionalnih narodnih knjižnica.

Na pitanje Je li knjižnica tijekom 2019. i/ili početkom 2020. godine (do početka epidemije) imala aktivan klub čitatelja, potvrdno su odgovorile 43 hrvatske knjižnice $^{32}$ (80 \% anketiranih knjižnica) te 22 slovenske knjižnice (71 \% anketiranih knjižnica). Najviše je narodnih knjižnica, u objema zemljama imalo po jedan čitateljski klub: u Hrvatskoj 83 \%, u Sloveniji 68 \%. Među knjižnicama s više klubova istaknula se jedna slovenska knjižnica s čak 16 klubova čitatelja, dok je u Hrvatskoj jedna knjižnica navela 9 klubova. Istraživanjem su obuhvaćena 62 kluba iz 43 hrvatske narodne knjižnice i 47 klubova iz 22 slovenske narodne knjižnice.

\subsubsection{Djelovanje kluba prije pandemije bolesti COVID-19}

Ovom skupinom pitanja prikupljeni su podatci o 62 hrvatska kluba i 47 slovenskih klubova čitatelja. Postavljena su pitanja pomoću kojih su se namjeravale dobiti osnovne informacije o načinu rada kluba: načinu i učestalosti susreta, uporabi IKT alata, poteškoćama s kojima su se susretali u radu te je li klub nastavio s radom nakon početka pandemije.

Na pitanje o načinu susreta klubova prije pandemije ponuđena su tri odgovora zatvorenog tipa: uživo, online i oboje. Rezultati su prikazani u tablici 1.

\footnotetext{
31 Pritom je odgovorilo 7 knjižnica iz sustava Knjižnica grada Zagreba, koje su u ukupnom zbroju brojane kao jedna knjižnica.

3236 samostalnih knjižnica i 7 knjižnica iz sastava Knjižnica grada Zagreba.
} 
Tablica 1. Način organizacije susreta prije pandemije

\begin{tabular}{|l|c|c|c|}
\hline Način susreta kluba & uživo & online & oboje \\
\hline Hrvatska (62 kluba) & 54 & 1 & 7 \\
\hline Slovenija (47 klubova) & 37 & 7 & 3 \\
\hline
\end{tabular}

Iz podataka u tablici 1 vidljivo je da su sastanci uživo najučestaliji način klupskih susreta. U hrvatskim narodnim knjižnicama uživo se sastajalo 87 \% klubova, njih $11 \%$ kombiniralo je susrete uživo i online, a svega $2 \%$ klubova radilo je isključivo online. U slovenskim knjižnicama postotci su nešto drukčiji, ali također idu u prilog sastancima uživo: 79 \% klubova sastajalo se uživo, $6 \%$ klubova imalo je sastanke uživo i online, dok se $15 \%$ klubova sastajalo isključivo online. Na pitanje Jesu li i u koju su svrhu korišteni IKT alati u radu kluba prije pandemije? ispitanici su mogli među ponuđenim odgovorima odabrati više opcija. Rezultati su prikazani u tablici 2.

Tablica 2. Svrha uporabe IKT alata

\begin{tabular}{|l|c|c|}
\hline $\begin{array}{l}\text { Jesu li i u koju su svrhu korišteni IKT alati u radu } \\
\text { kluba prije pandemije? }\end{array}$ & $\begin{array}{c}\text { Hrvatska } \\
\text { (62 kluba) }\end{array}$ & $\begin{array}{c}\text { Slovenija } \\
\text { (47 klubova) }\end{array}$ \\
\hline $\begin{array}{l}\text { Da, za komunikaciju (dogovaranje susreta, odabir } \\
\text { knjige za čitanje...) }\end{array}$ & 41 & 17 \\
\hline Da, za promociju kluba i privlačenje novih članova & 38 & 31 \\
\hline $\begin{array}{l}\text { Da, za virtualne susrete (komentiranje i rasprava o } \\
\text { pročitanim knjigama) }\end{array}$ & 4 & 10 \\
\hline Ne, nisu korišteni IKT alati & 8 & 11 \\
\hline
\end{tabular}

Iz podataka prikazanih u tablici 2 proizlazi da je $87 \%$ hrvatskih klubova čitatelja i $77 \%$ slovenskih klubova upotrebljavalo IKT alate u svom radu. Klubovi u Hrvatskoj tim su se alatima u najvećoj mjeri (76\%) koristili za dogovaranje susreta, odabir knjige i druge komunikacijske potrebe te za promociju kluba i privlačenje novih članova $(70 \%)$. Za virtualne susrete (komentiranje i raspravu o pročitanim knjigama) IKT alate upotrebljavalo je svega $7,4 \%$ onih koji su potvrdno odgovorili na pitanje, odnosno 6,5 \% ukupnog broja klubova čitatelja. Kod slovenskih klubova čitatelja, njih $47 \%$ upotrebljavalo je IKT alate za dogovaranje susreta, odabir knjige i sl., njih $86 \%$ za promociju kluba i privlačenje novih članova, a njih $28 \%$ za virtualne susrete, odnosno $21 \%$ ukupnog broja klubova. 
Sljedeće je pitanje bilo namijenjeno samo knjižnicama koje su potvrdno odgovorile na pitanje o uporabi IKT alata. Ponuđeni odgovori sadržavali su neke poznatije IKT alate koji već imaju široku primjenu u knjižničarstvu te jedan odgovor otvorenog tipa (ostalo) za nadopunu onim alatima koji nisu bili navedeni. U tablici 3 prikazano je koji su se IKT alati upotrebljavali u radu klubova čitatelja prije pandemije.

Tablica 3. Korišteni IKT alati

\begin{tabular}{|l|c|c|}
\hline Alati informacijsko-komunikacijske tehnologije & $\begin{array}{c}\text { Hrvatska } \\
\text { (47 klubova) }\end{array}$ & $\begin{array}{c}\text { Slovenija } \\
\text { (47 klubova) }\end{array}$ \\
\hline e-mail & 30 & 36 \\
\hline Facebook-stranica Knjižnice & 39 & 30 \\
\hline Facebook-grupa kluba & 18 & 1 \\
\hline blog & 0 & 1 \\
\hline WhatsApp & 16 & 0 \\
\hline Zoom & 3 & 9 \\
\hline mrežne stranice knjižnice & 38 & 31 \\
\hline ostalo & 9 & 4 \\
\hline
\end{tabular}

Iz tablice 3 vidljivo je da su hrvatske i slovenske knjižnice u najvećoj mjeri upotrebljavale uobičajene IKT alate: e-mail, Facebook-stranicu Knjižnice i mrežnu stranicu Knjižnice. U rubrici ostalo navedeni su još Viber, mrežna stranica Kluba; povremeno aplikacija Doodle, Facebook Messenger-chat i videopoziv, Instagram, Twitter. S obzirom na relativno malu zastupljenost klubova koji su održavali virtualne susrete (4 hrvatska i 10 slovenskih klubova), pretpostavlja se da su ti susreti održavani putem aplikacije Zoom, zatim Facebook-stranice Kluba ili Messengera. U usporedbi sa Slovenijom, utvrđuje se da veći broj hrvatskih klubova čitatelja ima vlastitu Facebook-grupu. Znatan broj hrvatskih klubova za komunikaciju koristi se WhatsAppom, a nijedan slovenski klub ne koristi se tom aplikacijom.

Pitanje Koje su glavne poteškoće u radu Kluba prije korone? nije nudilo zatvorene odgovore, već su ih ispitanici sami formulirali. U tablici 4 prikazane su najčešće poteškoće u radu, odnosno poteškoće koje su prisutne u najmanje dvama klubovima. 
Tablica 4. Poteškoće u radu klubova prije pandemije

\begin{tabular}{|l|c|c|}
\hline Poteškoće u radu klubova & $\begin{array}{c}\text { Hrvatska } \\
\text { (62 kluba) }\end{array}$ & $\begin{array}{c}\text { Slovenija } \\
\text { (47 klubova) }\end{array}$ \\
\hline Nisu imali poteškoća u radu & 24 & 37 \\
\hline Nedovoljan broj primjeraka za čitanje & 14 & 3 \\
\hline $\begin{array}{l}\text { Termin sastanka koji bi odgovarao većini članova s } \\
\text { obzirom na njihove obveze }\end{array}$ & 20 & 1 \\
\hline $\begin{array}{l}\text { Neredovitost dolazaka na sastanke i loša priprema } \\
\text { članova (nepročitana knjiga) }\end{array}$ & 4 & 0 \\
\hline Nedostatak prostora u kojem bi se sastajali & 1 & 1 \\
\hline Pridobivanje novih članova & 1 & 2 \\
\hline
\end{tabular}

Analizom odgovora navedenih u tablici 4 utvrđeno je da $39 \%$ klubova čitatelja u Hrvatskoj i 79 \% klubova u Sloveniji prije pandemije nije imalo poteškoća u radu. Voditelji ostalih klubova navode različite probleme, kao što je prikazano u gornjoj tablici.

Pitanjem Je li klub nastavio s radom i tijekom pandemije? utvrđeno je kako su od 62 kluba čitatelja u Hrvatskoj s radom tijekom pandemije nastavila 33 kluba (53\%). U Sloveniji je od 47 s radom nastavilo 19 (40 \%) klubova.

\subsubsection{Rad kluba tijekom pandemije bolesti COVID-19}

Ovim segmentom prikupljeni su podatci o 33 kluba u Hrvatskoj i 19 klubova čitatelja u Sloveniji. Kako bi prikupljeni podatci mogli biti usporedivi, postavljena su ista pitanja kao za prethodno razdoblje. Dodatno su postavljena pitanja vezana za aktivnosti klubova tijekom razdoblja zatvaranja i planove klubova za razdoblje nakon završetka pandemije, kako bi se dobio pobliži uvid u prilagodbe klubova tom specifičnom razdoblju.

U tablici 5 prikazani su podatci o načinu održavanja susreta (uživo, online ili kombinacijom jednoga i drugog načina) u navedenom razdoblju.

Tablica 5. Način susreta tijekom pandemije

\begin{tabular}{|l|c|c|c|}
\hline Način susreta kluba & uživo & online & oboje \\
\hline Hrvatska (33 kluba) & 9 & 11 & 13 \\
\hline Slovenija (19 klubova) & 4 & 9 & 6 \\
\hline
\end{tabular}

Prema podatcima predočenim u tablici 5., u hrvatskim narodnim knjižnicama uživo se sastajalo $27 \%$ klubova, online $33 \%$ klubova, a kombinirani način susreta ostvarilo je $39 \%$ klubova. U Sloveniji je sastanke uživo održavalo $21 \%$ klubova, online njih $47 \%$, a kombinirane susrete $32 \%$ klubova čitatelja. 
Na pitanje zatvorenog tipa Je li klub imao ikakvih aktivnosti tijekom lockdowna, (nedostupnosti i potpune zatvorenosti knjižnica)? više od polovice klubova u Hrvatskoj (njih 18 ili 55 \%) i u Sloveniji (njih 10 ili 53 \%) odgovorilo je da nije imalo nikakvih aktivnosti tijekom lockdowna.

Sljedeće pitanje - Ako je bilo aktivnosti tijekom lockdowna, napišite koje su to aktivnosti i koliko su učestale bile - bilo je namijenjeno ispitanicima koji su potvrdno odgovorili na prethodno pitanje: 15 hrvatskih i 9 slovenskih klubova. Među hrvatskim odgovorima iz nekih je opisa aktivnosti lako moguće zaključiti da su se provodile u virtualnom obliku (Objava sadržaja vezanih uz knjige preko naše Facebook stranice; Virtualni književni susret u Noći knjige), iz nekih da su imali kombinirane aktivnosti - virtualne i uživo na otvorenome (Virtualni sastanak, sastanak uživo izvan knjižnice na otvorenom). Za određeni broj aktivnosti način provedbe prema obliku odgovora nije se mogao utvrditi (Komunikacija s članovima kluba, izmjena knjiga. Biranje naslova za čitanje). Međutim, zbog strogih mjera koje su tada bile uvedene, kao i na temelju potvrdnog odgovora o uporabi IKT alata, $\mathrm{s}$ velikom se sigurnošću može pretpostaviti da se radilo o virtualnim aktivnostima. Iz svih slovenskih odgovora vidljivo je da se radi o virtualnim aktivnostima: Komunikacija putem e-alata; Komunikacija putem e-pošte - postavljamo si izazov čitanja, koji svaki član ispunjava pojedinačno, a zatim izvještava e-poštom.; Susret na internetu i sl.

S obzirom na to da su mjere fizičke distance i boravka ograničenog broja ljudi na određenom prostoru zadržane i nakon razdoblja zatvaranja, pitanje o upotrebi IKT alata u radu kluba odnosilo se na cjelokupno razdoblje pandemije. Pitanjem Koriste li se IKT alati u radu kluba tijekom pandemije? htjelo se istražiti u kojoj su mjeri klubovi iskoristili te alate za prevladavanje ograničenja vezanih za susrete uživo i za održavanje kontinuiteta njihova rada. Ponuđeni odgovori dali su mogućnost višestrukog izbora ako su bili potvrdnog karaktera. U tablici 6 prikazano je u kojem su se broju klubovi koristili IKT alatima u određenu svrhu.

Tablica 6. Svrha upotrebe IKT alata tijekom pandemije

\begin{tabular}{|l|c|c|}
\hline Svrha upotrebe IKT alata u radu kluba & $\begin{array}{c}\text { Hrvatska } \\
\text { (33 kluba) }\end{array}$ & $\begin{array}{c}\text { Slovenija } \\
\text { (19 klubova) }\end{array}$ \\
\hline $\begin{array}{l}\text { Da, za komunikaciju (dogovaranje susreta, odabir } \\
\text { knjige za čitanje..) }\end{array}$ & 27 & 16 \\
\hline Da, za promociju kluba i privlačenje novih članova & 15 & 10 \\
\hline $\begin{array}{l}\text { Da, za virtualne susrete (komentiranje i rasprava o } \\
\text { pročitanim knjigama) }\end{array}$ & 20 & 12 \\
\hline Ne, nisu korišteni IKT alati & 4 & 2 \\
\hline
\end{tabular}


Prikupljeni rezultati govore da je $88 \%$ hrvatskih klubova i $89 \%$ slovenskih klubova upotrebljavalo IKT alate u svom radu tijekom pandemije. Tim su se alatima u najvećoj mjeri koristili za dogovaranje susreta, odabir knjige i druge komunikacijske potrebe (u Hrvatskoj $93 \%$, u Sloveniji $94 \%$ ), zatim za virtualne susrete (u Hrvatskoj 69 \%, u Sloveniji 71 \%), a promocija kluba i privlačenje novih članova bili su tek treći razlog uporabe IKT alata tijekom pandemije (u Hrvatskoj $52 \%$, u Sloveniji $59 \%$ ).

Slijedilo je pitanje o vrsti upotrebljenih IKT alata. Pitanjem se htjelo utvrditi jesu li se dogodile promjene u odnosu na prethodno razdoblje, a u tablici 7 prikazani su dobiveni rezultati.

Tablica 7. Upotreba IKT alata tijekom pandemije

\begin{tabular}{|l|c|c|}
\hline Alati informacijsko-komunikacijske tehnologije & $\begin{array}{c}\text { Hrvatska } \\
\text { (33 kluba) }\end{array}$ & $\begin{array}{c}\text { Slovenija } \\
\text { (19 klubova) }\end{array}$ \\
\hline e-mail & 17 & 18 \\
\hline Facebook-stranica Knjižnice & 19 & 11 \\
\hline Facebook-grupa kluba & 13 & 1 \\
\hline blog & 0 & 0 \\
\hline WhatsApp & 11 & 0 \\
\hline Zoom & 13 & 11 \\
\hline mrežne stranice knjižnice & 17 & 14 \\
\hline ostalo & 8 & 1 \\
\hline
\end{tabular}

Iz prikazanih se podataka zaključuje da su se klubovi i tijekom pandemije gotovo u jednakom omjeru nastavili služiti e-mailom, Facebook-stranicom Knjižnice i mrežnom stranicom Knjižnice. Jedino se kod aplikacije Zoom uočava porast upotrebe u objema zemljama. Pod ostalo navedeni su neki novi alati koji nisu bili upotrebljavani prije pandemije: Edmodo, Discord, Google Meet i Linoit.

Pitanjem o poteškoćama u radu kluba tijekom pandemije htjelo se saznati u kojoj su mjeri poteškoće, ako su postojale u radu, uzrokovane aktualnom epidemiološkom situacijom i njezinim posljedicama, a u kojoj se mjeri radi o uobičajenim problemima u radu klubova. U tablici 8 prikazane su poteškoće koje su utvrđene kod dvaju ili više klubova. Kako se radilo o pitanju otvorenog tipa, tako se radi lakše usporedbe odgovore grupiralo na sličan način kao one prije pandemije. 
Tablica 8. Poteškoće u radu klubova tijekom pandemije

\begin{tabular}{|l|c|c|}
\hline Poteškoće u radu kluba & $\begin{array}{c}\text { Hrvatska } \\
\text { (33 kluba) }\end{array}$ & $\begin{array}{c}\text { Slovenija } \\
\text { (19 klubova) }\end{array}$ \\
\hline Nisu imali poteškoća u radu & 2 & 12 \\
\hline Nemogućnost susreta uživo & 16 & 4 \\
\hline Problem s korištenjem IKT alata & 2 & 2 \\
\hline Strah od bolesti i briga za zdravlje članova HR & 6 & 1 \\
\hline $\begin{array}{l}\text { Termin sastanka koji bi odgovarao većini članova s } \\
\text { obzirom na njihove obveze }\end{array}$ & 2 & - \\
\hline Neredovitost dolazaka na sastanke & 2 & - \\
\hline
\end{tabular}

Analizom odgovora prikazanih u tablici 8 utvrđeno je da svega $6 \%$ klubova u Hrvatskoj nije imalo poteškoća u radu, dok je u Sloveniji bez poteškoća radilo njih $63 \%$. Preostali klubovi, 31 hrvatski klub i 7 slovenskih klubova, naveli su jednu ili više poteškoća u radu tijekom pandemije. Rezultati analize pokazuju da je nemogućnost susreta uživo najučestalija poteškoća klubova u Hrvatskoj (52 \%) i Sloveniji (57 \%). U radu hrvatskih klubova sljedeći problem po učestalosti, strah od bolesti i briga za zdravlje članova, prisutan je kod $19 \%$ klubova, dok je u Sloveniji taj problem bio na trećem mjestu i zastupljen je kod $14 \%$ klubova.

Na pitanje otvorenog tipa Kada se ponovno steknu uvjeti za redovan rad, koji su planovi kluba? odgovorili su svi ispitanici. Slobodno oblikovani odgovori, kako bi poslužili svrsi provedenog istraživanja, sistematizirani su prema vrsti aktivnosti na one koje se provode uživo i na online aktivnosti. U Hrvatskoj je 98 \% klubova navelo da planiraju aktivnosti uživo kada se ponovno steknu uvjeti za redovan rad, a nijedan ne navodi planiranje online aktivnosti. U Sloveniji su se svi ispitanici $(100 \%)$ izjasnili za susrete uživo, a samo je jedan ispitanik naveo i mogućnost provođenja online aktivnosti u slučaju da ih ne bude moguće provoditi uživo.

\subsubsection{Prestanak rada kluba}

Skupina pitanja o prestanku rada kluba bila je namijenjena knjižnicama čiji klubovi čitatelja tijekom pandemije nisu nastavili s radom: 29 klubova u Hrvatskoj i 18 klubova u Sloveniji. ${ }^{33}$ Za utvrđivanje uzroka prestanka rada ispitanicima je ponuđeno više odgovora s mogućnošću višestrukog izbora. Dio ponuđenih odgovora predstavljao je razloge koji se izravno mogu povezati s pandemijom bolesti COVID-19: Zbog specifičnih uvjeta rada tijekom pandemije, Zbog lockdowna,

33 U Sloveniji 28 klubova nije nastavilo s radom, međutim knjižnica koja je u jednom upitniku dala podatke za više čitateljskih klubova, od kojih su neki prestali s radom, na pitanja u ovoj skupini nije mogla odgovoriti. 
Zbog straha članova od zaraze; a dio uobičajene razloge: Spontano - gubitak interesa članova ili voditelja, Klub je ostao bez voditelja. U odgovorima hrvatskih klubova bili su zastupljeni svi ponuđeni razlozi, a kod slovenskih klubova nisu zastupljeni razlozi koje ne povezujemo s pandemijom.

Radi boljeg razumijevanja razloga prestanka rada ispitano je jesu li klubovi tijekom pandemije uopće pokušali održati online sastanak. Pretpostavljeno je da ga nisu uspjeli održati, pa su u ponuđenim odgovorima zatvorenog tipa navedeni neki očekivani razlozi za to i ponuđena je mogućnost za dopunu razloga u odgovoru otvorenog tipa (Ostalo). Rezultati su predočeni u tablici 9.

Tablica 9. Pokušaj održavanja online sastanka

\begin{tabular}{|l|c|c|}
\hline $\begin{array}{l}\text { Jeste li tijekom pandemije pokušali održati } \\
\text { online sastanak? }\end{array}$ & $\begin{array}{c}\text { Hrvatska } \\
\text { (29 klubova) }\end{array}$ & $\begin{array}{c}\text { Slovenija } \\
\text { (18 klubova) }\end{array}$ \\
\hline DA, ali nije se svidjelo članovima & 2 & 3 \\
\hline DA, ali nije zaživjelo zbog tehničkih poteškoća & 1 & 0 \\
\hline NE, ali namjeravamo & 3 & 2 \\
\hline NE jer nemamo tehničke mogućnosti & 4 & 1 \\
\hline NE jer članovi ne poznaju dovoljno tehnologiju & 7 & 3 \\
\hline $\begin{array}{l}\text { NE jer bez fizičkog kontakta klub čitatelja nema } \\
\text { smisla }\end{array}$ & 8 & 5 \\
\hline Ostalo & 4 & 4 \\
\hline
\end{tabular}

Iz tablice 9 vidljivo je da je manji broj klubova pokušao održati online sastanak: tri hrvatska kluba (10\% onih koji su prestali s radom) i tri slovenska kluba (17\%). Među niječnim odgovorima u objema se zemljama ističe razlog NE jer bez fizičkog kontakta Klub čitatelja nema smisla kao najzastupljeniji. Pod Ostalo navedeno je da članovi imaju previše školskih obveza ili žele jedino sastanke uživo, neki održavaju kontakt telefonom, a neki smatraju da ,voditelj kluba ne bi mogao adekvatno voditi računa o potrebama članova tijekom sastanka preko ekrana“. Posljednje pitanje u skupini bilo je Jeste li za vrijeme pandemije osnovali novi klub čitatelja?, a svi su ispitanici, 29 hrvatskih i 18 slovenskih klubova, odgovorili niječno.

Isto pitanje postavljeno je i knjižnicama koje tijekom 2019. i/ili početkom 2020. godine (do početka pandemije) nisu imale aktivan klub čitatelja: 17 hrvatskih i 9 slovenskih knjižnica. Jedna hrvatska knjižnica odgovorila je potvrdno i navela da su se sastajali uživo i online. U Sloveniji je svih 9 knjižnica odgovorilo niječno. 


\subsection{Rasprava i zaključci iz istraživanja}

Klubovi čitatelja na različite su se načine suočili s otežanim uvjetima rada knjižnica nakon proglašenja pandemije bolesti COVID-19. U istraživanju su sudjelovale 43 hrvatske knjižnice i 22 slovenske knjižnice koje su tijekom 2019. i početkom 2020. godine imale aktivan jedan ili više čitateljskih klubova. Od 62 aktivna hrvatska kluba čitatelja prije pandemije, njih 33 (53 \%) nastavilo je s radom tijekom pandemije. U Sloveniji je udio klubova koji su nastavili s radom bio nešto niži jer je od 47 aktivnih klubova tijekom pandemije s radom nastavilo 19 klubova (40\%).

Proučavanjem mrežnih stranica narodnih knjižnica u objema zemljama uočeno je da, uz to što nisu sve knjižnice sudjelovale u istraživanju, nisu se predstavili ni svi klubovi knjižnica koje jesu ispunile anketni upitnik. Pretpostavlja se da je to prouzročeno načinom prikupljanja podataka jer se tražilo da se za svaki klub ispuni zaseban anketni upitnik te da ga ispuni voditelj kluba ili knjižničar koji prati rad toga kluba, a vjerojatno nisu svi voditelji bili zainteresirani za sudjelovanje u istraživanju.

Većina klubova koje su vodili volonteri u pandemiji je obustavila sve aktivnosti. Tako je u Hrvatskoj od 15 volonterskih klubova samo njih pet imalo susrete ili neki drugi oblik aktivnosti tijekom pandemije. Slično je bilo i u Sloveniji gdje su svega dva kluba od njih 14 nastavila susrete u novim okolnostima. Kod ovog parametra pretpostavilo se da će s radom nastaviti više klubova koje vode djelatnici knjižnice jer imaju profesionalni interes da klubovi opstanu. Dubljom analizom i usporedbom prikupljenih podataka o aktivnim klubovima prije i tijekom pandemije pretpostavka je potvrđena, te je utvrđeno da su u objema zemljama u podjednakim omjerima većinom s radom nastavljali klubovi kojima su voditelji knjižničari: u Sloveniji je s radom nastavilo $11 \%$ volontera i 74 \% knjižničara, a u Hrvatskoj je s radom nastavilo $15 \%$ volontera i $70 \%$ knjižničara.

Pandemija je eskalirala brzo i neočekivano, pa su tako i epidemiološke mjere naglo promijenile način života i rada. Posebno je teško bilo na samom početku pandemije kada je tijekom lockdowna u objema zemljama došlo do potpune zatvorenosti knjižnica, pa knjižnični prostor i knjižnična građa u fizičkom obliku nisu bili dostupni korisnicima. U anketnom upitniku pitanja o aktivnostima klubova tijekom lockdowna postavljena su kako bi se vidjelo kako su se klubovi čitatelja snašli u tom razdoblju najstrožih epidemioloških mjera. Istraživanjem je utvrđeno da je svega 15 hrvatskih (24\%) i 9 slovenskih (19\%) klubova koji su bili aktivni prije pandemije nastavilo provoditi aktivnosti na daljinu tijekom lockdowna. Klubovi navode virtualne aktivnosti poput sastanaka na daljinu, objava preko Facebook-stranice knjižnice i u Facebook-grupi kluba, korištenje WhatsAppom za razmjenu poruka podrške, razmjene razmišljanja o pročitanoj knjizi e-poštom i dr. s više ili manje uspjeha. Analizom odgovora uočeno je da su pojedini voditelji 
klubova pokušavali održati online susrete, međutim članovi su takvu mogućnost a priori odbacivali inzistirajući na susretu uživo čim to epidemiološke mjere dopuste ili su pristali na susret na daljinu, ali im se takav način rada nije svidio. Tako jedan ispitanik navodi: „Bilo je pokušaja da rasprave o knjigama vodimo na internetu, ali to nije zaživjelo". Na samom početku pandemije ljudi su se suočili s velikim promjenama u načinu života i trebalo se prilagoditi na raznim područjima. Razlog preferiranja susreta uživo u ovom razdoblju možda se nalazi u nespremnosti da se društveni život prebaci u virtualni svijet zbog očekivanja brzog završetka pandemije i povratka uobičajenom načinu rada.

S obzirom na to da su tijekom pandemije uvedena brojna ograničenja za okupljanja uživo, a u vrijeme lockdowna i njihova potpuna zabrana, pitanje načina susreta klubova nametnulo se kao jedno od temeljnih istraživačkih pitanja. Prije pandemije najučestaliji način klupskih susreta bili su sastanci uživo, pa se $87 \%$ hrvatskih i 79 \% slovenskih klubova čitatelja sastajalo uživo u knjižnicama. Prema prikupljenim podatcima o načinu susretanja tijekom pandemije uočava se preokret, pa susreti uživo postaju najmanje zastupljeni: u Hrvatskoj se uživo nastavilo sastajati $27 \%$, a u Sloveniji $21 \%$ klubova. Tijekom pandemije u Hrvatskoj je najviše čitateljskih klubova, njih $39 \%$, kombiniralo susrete uživo i online (prije pandemije $11 \%$ ), a potpuno online susretalo se $33 \%$ (prije pandemije svega $2 \%$ ) klubova. Izrazit porast online susreta dogodio se i u Sloveniji, gdje je prije pandemije isključivo takav oblik rada bio prisutan kod $15 \%$ klubova, a tijekom pandemije postao je najzastupljeniji oblik rada jer je $47 \%$ klubova održavalo susrete na daljinu. U Sloveniji je porastao i udio klubova koji su imali kombinirane susrete uživo i online s prijašnjih $6 \%$ na $32 \%$ klubova tijekom pandemije. Rezultati potvrđuju da su, kao što je u uvodnom dijelu rada pojašnjeno, promijenjeni uvjeti poslovanja potaknuli narodne knjižnice da dio svojih sadržaja premjeste u virtualni prostor, a nužnost održavanja fizičke distance i dugo trajanje pandemije usmjerili su ljude da uporabom suvremenih IKT alata smanje osjećaj izolacije i zadovolje potrebu za osjećajem povezanosti s drugima.

Budući da su socijalne mjere u početnom razdoblju pandemije bile izrazito stroge, a u kasnijem razdoblju bile s više ili manje intenziteta i dalje prisutne, upotreba IKT alata postala je važna za održanje kontinuiteta rada klubova. S obzirom na specifičnost situacije, pod pojmom kontinuitet rada misli se u širem smislu na održavanje kontakta među članovima dok se čeka prilika za susret uživo, a u užem smislu na prelazak na održavanje susreta online. Analiza podataka pokazala je da je uporaba IKT alata među hrvatskim klubovima čitatelja bila podjednaka prije (87\%) i tijekom pandemije ( $88 \%$ ), dok su se slovenski klubovi znatno više koristili tim alatima tijekom pandemije (90\%) nego prije (77\%). Hrvatski klubovi koji su potvrdno odgovorili na pitanje o uporabi IKT alata tim su se alatima istovremeno koristili u različite svrhe. Tijekom pandemije u najvećoj su ih mjeri upotrebljavali za dogovaranje susreta, odabir knjige i druge komunikacijske po- 
trebe, njih $93 \%$ (prije pandemije $76 \%$ ), zatim za virtualne susrete, odnosno za komentiranje i raspravu o pročitanim knjigama, njih $69 \%$ (prije svega $6 \%$ ) te nešto manje za promociju kluba i privlačenje novih članova, $52 \%$ klubova (prije 70 \%). I u slovenskim klubovima IKT alati u najvećoj su se mjeri upotrebljavali za dogovaranje susreta, odabir knjige i druge komunikacijske potrebe kod $94 \%$ klubova (prije pandemije $4 \%$ ), zatim za virtualne susrete, komentiranje i raspravu o pročitanim knjigama, kod njih $71 \%$ (prije $28 \%$ ) te za promociju kluba i privlačenje novih članova kod 59 \% klubova (prije $86 \%$ ). Uočavaju se značajne promjene u svrsi uporabe IKT alata prije i tijekom pandemije. Utvrđeno je da su se tijekom pandemije dogodili identični procesi u objema zemljama: porast uporabe IKT alata u svrhu održavanja virtualnih susreta te smanjenje uporabe IKT alata za promociju klubova i privlačenje novih članova. Navedene promjene upućuju na to da se većina klubova čitatelja pri suočavanju s pandemijom podjednako usredotočila na zadržavanje kontinuiteta rada kluba u širem i u užem smislu, pa se više pažnje posvećivalo održavanju kontakta s članovima nego promociji klubova i privlačenju novih članova. Rezultati pokazuju da su voditelji i članovi klubova čitatelja prepoznali, kako je istaknuto u teoretskom uvodu, da osjećaj pripadnosti nekoj grupi koja dijeli interese i u kojoj ljudi međusobno pružaju podršku ohrabrenjem i razumijevanjem može ublažiti stresne uvjete života. To potkrepljuje navod ispitanice o provedenim aktivnostima: tri Zoom susreta, WhatsApp s porukama podrške i igrama.

Navedeni zaključak potvrđuje i usporedba tipova IKT alata koji su upotrebljavani prije s onima upotrebljavanima tijekom pandemije, osobito upotreba aplikacije Zoom. Radi se o besplatnoj aplikaciji za konferencijske/grupne videopozive koja pripada novijim internetskim komunikacijskim rješenjima s obzirom na to da je u upotrebi od 2011. godine, a tijekom pandemije postala je gotovo sinonim za susrete online, poslovne, edukativne ili privatne prirode. ${ }^{34} \mathrm{Od} 4$ hrvatska kluba (6\%) koji su prije pandemije održavali virtualne susrete samo se jedan klub u tu svrhu koristio Zoomom. Tijekom pandemije virtualne sastanke održavalo je 20 klubova (61 \% aktivnih klubova), pri čemu se Zoomom koristilo 13 klubova (39\%), od toga njih 11 (33\%) za virtualne sastanke, a 2 (6 \%) za komunikaciju s članovima. Dakle, tijekom pandemije jedanaest puta više klubova koristi se Zoomom za održavanje susreta na daljinu nego prije pandemije. U Sloveniji je promjena nešto manje izražena. Prije pandemije Zoomom se za održavanje virtualnih susreta koristilo 9 klubova, odnosno 25 \% klubova koji su se izjasnili da

\footnotetext{
34 Chawla, A. Coronavirus (COVID-19): 'Zoom' application boon or bane. // Social Science Research Network, 2020. [citirano: 2021-01-25]. Dostupno na: https://papers.ssrn.com/sol3/papers. cfm?abstract_id=3606716.; Vidjeti i: Wiederhold, B. K. Connecting through technology during the Coronavirus disease 2019 Pandemic: Avoiding "Zoom fatigue". // Cyberpsychology, Behavior, and Social Networking 23, 7(2020), str. 437-438. [citirano: 2021-01-25]. Dostupno na: https://www.liebertpub.com/doi/pdfplus/10.1089/cyber.2020.29188.bkw.
} 
su upotrebljavali IKT alate. Tijekom pandemije 12 je klubova (71\%) navelo da organizira susrete na daljinu, a pritom ih 11 (65\%) upotrebljava Zoom.

Razmišljanjem o fizičkoj nedostupnosti knjižnica i primjeni digitalnih alata logično se dolazi i do pitanja o upotrebi $e$-knjige. Kako je u Hrvatskoj $e$-knjiga prisutna tek sporadično, za razliku od Slovenije u kojoj je digitalna platforma za posudbu $e$-knjige Biblos dostupna na nacionalnoj razini, ${ }^{35}$ tako anketni upitnik nije sadržavao pitanje koje bi se neposredno odnosilo na upotrebu $e$-knjige u radu klubova, ali je u pitanjima s otvorenim odgovorima postojala takva mogućnost. Promatrajući rezultate, zanimljivo je da nitko od ispitanika u Hrvatskoj nije naveo $e$-knjigu, bilo kao poteškoću u radu klubova onih knjižnica koje nemaju $e$-knjige u svojoj ponudi, bilo kao olakotnu okolnost klubova u knjižnicama koje ih imaju. Među odgovorima slovenskih ispitanika, samo je jedan u kojemu se spominje e-knjiga: ,,Srećom, u to smo vrijeme odabrali za čitanje knjigu dostupnu na Biblo$s u$ ". Navedeni podatci nisu dovoljni da bi se na temelju njih mogli donijeti bilo kakvi zaključci o upotrebi e-knjige u radu klubova prije i tijekom pandemije, ali se može zaključiti da voditelji klubova/knjižničari nisu percipirali $e$-knjigu važnom za isticanje.

Pitanjem o prisutnosti poteškoća u radu klubova prije i tijekom pandemije bolesti COVID-19 htjelo se utvrditi u kojoj je mjeri pandemija uzrokovala nove poteškoće u radu, koje su to teškoće i jesu li dovele do gašenja klubova. Usporedbom dobivenih rezultata utvrđeno je da je tijekom pandemije u objema zemljama porastao udio klubova s poteškoćama u radu. U Hrvatskoj je i za razdoblje prije pandemije zabilježen visok udjel od $61 \%$ čitateljskih klubova koji su u radu imali neku poteškoću. Tijekom pandemije postojanje poteškoća navelo je $94 \%$ klubova. U Sloveniji je prisutnost poteškoća, kao i zabilježena razlika između dvaju razdoblja, nešto manja, ali se također tijekom pandemije dogodio porast udjela klubova s poteškoćama u radu (37\%) u odnosu na razdoblje prije pandemije (21\%). Dodatnom analizom slobodno oblikovanih odgovora na pitanje o glavnim poteškoćama koje su imali u radu utvrđeno je da su dominantne poteškoće klubovima u Hrvatskoj prije pandemije bile „termin sastanka koji bi odgovarao većini članova s obzirom na njihove obveze (53\%) i nedovoljan broj primjeraka za čitanje“ (37\%). Tijekom pandemije dominantne poteškoće postale su nemogućnost susreta uživo $(5 \%)$ te „strah od bolesti i briga za zdravlje članova“ (19\%). Među malobrojnim slovenskim klubovima koji su imali poteškoća u radu najučestalije poteškoće prije pandemije bile su im ,nedovoljan broj primjeraka za čitanje (30\%) i pridobivanje novih članova“ (20\%), a tijekom pandemije „nemogućnost susreta uživo“ (57\%) i „problem s korištenjem IKT alata“ (29\%). Slijedom predstavljenih rezultata uočava se da je pandemija prouzročila nove poteškoće u radu klubova koje su istovremeno postale prevladavajuće. Poteškoće su zasigurno utjecale i na stav is-

35 Biblos: spletni distribucijski portal za elektronske knjige. [citirano: 2021-01-27]. Dostupno na: https://www.biblos.si/knjiznice. 
pitanika o planovima kada se steknu uvjeti za redovan rad s obzirom na to da su oni, prema rezultatima istraživanja, vezani isključivo uz aktivnosti uživo.

Kod dijela klubova pandemija je prouzročila i potpuni prekid rada: u Hrvatskoj $47 \%$, u Sloveniji $38 \%$ anketiranih klubova. Među njihovim odgovorima ističu se stavovi kako „bez fizičkog kontakta klub čitatelja nema smisla“ i da“ članovi ne poznaju dovoljno tehnologiju“", stoga nisu ni pokušavali održati sastanak online. O utjecaju pandemije na čitateljske klubove u značajnoj mjeri govori i podatak da je od početka pandemije u ožujku do provedbe istraživanja u studenome i prosincu (9 mjeseci) osnovan samo jedan čitateljski klub.

Povezujući navedene podatke o prekidu rada i poteškoćama s podatcima o najučestalijem načinu klupskih susreta prije pandemije i najzastupljenijim aktivnostima koje klubovi planiraju provoditi kada se steknu uvjeti za redovan rad, zaključuje se da susreti uživo imaju izuzetnu važnost za voditelje i za članove klubova. Mogući razlozi za preferiranje susreta uživo s jedne strane nalaze se u potrebi članova za živom i neposrednom komunikacijom s drugim ljudima, odnosno druženjem, ugodnim ambijentom i slično, a s druge strane u tehnološki uvjetovanim zahtjevima vezanim za susrete na daljinu, kao što su posjedovanje jake i stabilne internetske veze ili spretnost u snalaženju s određenom aplikacijom za videopozive i online-komunikacijom. To potkrepljuju teorijske postavke iz literature o tome da se susrete uživo ne može zadovoljavajuće zamijeniti primjenom IKT alata koji omogućuju ipak ograničenu i reduciranu komunikaciju.

\section{Zaključak}

Interes za klubove čitatelja jedna je od sličnosti koje povezuju Republiku Hrvatsku i susjednu Republiku Sloveniju. Istraživanjem je utvrđeno da su brojne hrvatske i slovenske narodne knjižnice prepoznale klub čitatelja kao vrijedan program za promicanje čitanja, kritičkog promišljanja i argumentirane rasprave o pročitanome uz druženje u prijateljskoj atmosferi. Koliko je taj program važan korisnicima knjižnica pokazuju rezultati istraživanja kojima je utvrđeno da je u Hrvatskoj od 62 aktivna kluba čitatelja prije pandemije, njih 33 (53\%) nastavilo s radom tijekom pandemije, dok je u Sloveniji od početnih 47 klubova s radom nastavilo njih 19 (40\%). Suprotno postavljenoj hipotezi istraživanja kojom se pretpostavilo da su pandemija bolesti COVID-19 i stroge epidemiološke mjere uzrokovale prestanak rada klubova čitatelja u narodnim knjižnicama, utvrđeno je da su se brojni klubovi vrlo brzo prilagodili novim okolnostima i nastavili s radom u virtualnom prostoru ili kombinirajući komunikaciju i susrete na daljinu sa susretima uživo kad je to bilo moguće. Iako među knjižničarima i korisnicima prevladava želja za susretima uživo, velik dio njih pronašao je način da iskoriste prednosti suvremene informacijske i komunikacijske tehnologije (IKT) kako bi održali kontinuitet rada klubova. Analiza svrhe upotrebe IKT alata pokazala je 
da se većina klubova čitatelja pri suočavanju s pandemijom usredotočila na komunikaciju među postojećim članstvom i održavanje virtualnih susreta, za što su primjenjivali sada već tradicionalne $e$-poštu i društvenu mrežu Facebook ili noviju tehnologiju poput aplikacija za slanje trenutačnih poruka (engl. instant messaging) i grupne videopozive. Istraživanjem je utvrđeno da je pandemija bolesti COVID-19 u objema zemljama ubrzala proces primjene novih tehnologija za grupne videopozive i potaknula znatan dio klubova čitatelja na održavanje virtualnih susreta. Istovremeno se kontinuirano ističe želja za održavanjem susreta uživo. Neka buduća istraživanja nakon završetka pandemije mogla bi pokazati radi li se kod održavanja isključivo virtualnih susreta te kod kombiniranja susreta uživo i na daljinu samo o privremenoj promjeni ili je pandemija uzrokovala trajnu promjenu rada klubova.

\section{LITERATURA}

Bašić, I. O čitateljskim grupama: Metodički priručnik s primjerima dobre prakse. Zagreb: Balans centar za logopedagogiju i biblioterapiju, 2014.

Baza čitateljskih klubova. // Hrvatsko čitateljsko društvo. [citirano 2020-12-20]. Dostupno na: http://hcd.hr/registracija-citateljski-klubova.

Begić, D.; A. Lauri Korajlija; N. Jokić-Begić. Psihičko zdravlje liječnika u Hrvatskoj za vrijeme pandemije COVID-19. // Liječnički vjesnik 142, 7/8(2020), 189-198. [citirano: 2020-12-20]. Dostupno na: https://hrcak.srce.hr/243213.

Biblos: spletni distribucijski portal za elektronske knjige. [citirano: 2021-01-27]. Dostupno na: https://www.biblos.si/knjiznice.

Bokan, A.; D. Cupar. Promocija i promicanje čitanja u narodnim knjižnicama Republike Hrvatske. // Libellarium 10, 1(2017), 51-76. DOI: http://dx.doi.org/10.15291/ libellarium.v1i1.290.

Bubić, A. Kako se nositi sa situacijom prouzrokovanom pandemijom koronavirusne bolesti (COVID-19)? Zagreb: Naklada Slap, 2020. [citirano 2021-01-15] Dostupno na: http://www.nakladaslap.com/public/docs/knjige/ostanidoma-covid-19.pdf.

Chawla, A. Coronavirus (COVID-19): 'Zoom' application boon or bane. // Social Science Research Network, 2020. [citirano: 2021-01-25]. Dostupno na: https://papers.ssrn.com/sol3/papers.cfm?abstract_id=3606716.

COVID-19 bolest. // Hrvatska enciklopedija. Mrežno izd. Leksikografski zavod Miroslav Krleža. [citirano 2021-01-20]. Dostupno na: http://www.enciklopedija.hr/ Natuknica.aspx?ID=70912.

Čitateljski klub Knjižnice I. B. Mažuranić. Facebook grupa. [citirano: 2021-01-15]. Dostupno na: https://www.facebook.com/groups/144815659013627/. 
Duić, M.; M. Anđić. Čitateljski klubovi u narodnim knjižnicama velikih hrvatskih gradova. // Vjesnik bibliotekara Hrvatske 62, 2(2019), 89-111. DOI: https://doi. org/10.30754/vbh.62.2.764.

Gruzd, A.; D. Rehberg Sedo. \#1b1t: Investigating reading practices at the turn of the twenty-first century. // Mémoires du livre. Studies in Book Culture 3, 2(2012), 1-25. DOI: https://doi.org/10.7202/1009347ar.

IFLA-ine smjernice za narodne knjižnice. / uredile C. Koontz i B. Gubbin. Zagreb: Hrvatsko knjižničarsko društvo, 2011.

Jokić Begić, N. Više će zbog psihoze koja se stvorila stradati psihičko zdravlje nego tjelesno. // Koronavirus i mentalno zdravlje: Psihološki aspekti, savjeti i preporuke. / uredila A. Bogdan i suradnici. Zagreb: Hrvatska psihološka komora, 2020. Str. $17-18$.

Kavčič, P. Intervju z Manco Košir: Dobre knjige nas berejo. // Knjižnica: Revija za področje bibliotekarstva in informacijske znanosti 61, 4(2017), 9-21. [citirano: 202012-23] Dostupno na: https://ojs-gr.zrc-sazu.si/knjiznica/article/view/6726.

Kelava, I.; M. Šimić. Čitateljski klubovi knjižnice Ivane Brlić Mažuranić u stvarnom i virtualnom svijetu. // Hrčak: Glasilo hrvatskog čitateljskog društva, 48/49(2014), str. 6. [citirano: 2020-12-21]. Dostupno na: https://issuu.com/hrcak_hcd/ docs/48_49_12_2014.

Kolarić, A.; S. Šimić; V. Štivić; Ž. Žentil Barić. Čitateljski blogovi Tragači i Knjiški frikovi: Usluge za djecu i mlade na Web-u 2.0. // Vjesnik bibliotekara Hrvatske 56, 3(2013), 91-100. Dostupno i na: https:/www.hkdrustvo.hr/vjesnik-bibliotekara-hrvatske/index.php/vbh/article/view/164/159.

Koordinacija osrednjih območnih knjižnic (OOK). // Narodna in univerzitetna knjižnica Slovenia. [citirano: 2020-12-28]. Dostupno na: https://www.nuk.uni-lj.si/nuk/ook

Lima, C. Reader's interactions in an online reading group. // Language and Literacy 19, 4(2017), 129-142. DOI: https://doi.org/10.20360/G21D4F.

Medved, K. Bralni klubi na portalu Dobreknjige.si. // Bukla: Brezplačna revija o dobrih knjigah 16, 157(2020), str. 50. [citirano 2020-12-23]. Dostupno na:

http://www.bukla.si. https://issuu.com/revijabukla/docs/bukla-157.

Milić Babić, M. Socijalna podrška i roditeljstvo. // Socijalne teme: Časopis za pitanja socijalnog rada i srodnih znanosti 1, 6(2019), 13-26. [citirano: 2021-01-21]. Dostupno na: https://hrcak.srce.hr/233278.

Montalto, V.; P. L. Sacco; V. Alberti; F. Panela; M. Saisana. European cultural and creative cities in COVID-19 times. // European Commission, JRC Science for Policy Report. Jobs at risk and the policy response. Luxembourg: Publications Office of the European Union, 2020. [citirano: 2021-03-20]. Dostupno na: https:/ec.europa. $\mathrm{eu} / \mathrm{jrc} / \mathrm{en} / \mathrm{publication} / \mathrm{eur}$-scientific-and-technical-research-reports/european-cultural-and-creative-cities-covid-19-times. 
Muslić, Lj. Koronavirus kao prijetnja mentalnom zdravlju. // Koronavirus i mentalno zdravlje: Psihološki aspekti, savjeti i preporuke. / uredila A. Bogdan i suradnici. Zagreb: Hrvatska psihološka komora, 2020. Str. 13-17. [citirano 2020-12-20]. Dostupno na: http://psiholoska-komora.hr/static/documents/HPK-Koronavirus_i_mentalno_zdravlje.pdf.

Odluka o proglašenju epidemije bolesti COVID-19 uzrokovane virusom SARS-Cov-2 na području čitave Republike Hrvatske. // Ministarstvo zdravstva Republike Hrvatske, 2020. [citirano 2020-12-20]. Dostupno na: https://zdravlje.gov.hr/koronavirus-i-mjere-prevencije/4952.

Perković, I. Stručni skup: Čitateljski klubovi i grupe u Hrvatskoj. // Moderna vremena info: e-zine \& portal za knjigu i kulturu čitanja, 2014. [citirano 2020-12-20]. Dostupno na: https://mvinfo.hr/clanak/strucni-skup-itateljski-klubovi-i-grupe-u-hrvatskoj.

Rebergh Sedo, D. Readers in reading groups: an online survey of face-to-face and virtual book clubs. // Convergence: The International Journal of Research into New Media Technologies 9, 1(2003), 66-90. [citirano: 2021-01-10]. Dostupno na: https://www.researchgate.net/publication/249828932_Readers_in_Reading_GroupsAn_Online_Survey_of_Face-to-Face_and_Virtual_Book_Clubs.

Slovenija razglasila epidemijo novega koronavirusa. // Republika Slovenija: GOV.SI, 2020. [citirano 2021-08-31]. Dostupno na: https://www.gov.si/novice/2020-03-12-slovenija-razglasila-epidemijo-novega-koronavirusa.

Slovenske splošne knjižnice. // Portal slovenskih splošnih knjižnic. [citirano: 2020-1228]. Dostupno na: https://www.knjiznice.si/.

Smjernice za knjižnične usluge za mladež: prerađeno izdanje Smjernica koje je 1996. objavio Stalni odbor Sekcije knjižnica za djecu i mladež / priređivači P. Muller, I. Chew, A. Jurinović i K. Zauder. Web 2.0 i knjižnične usluge za mladež: Uvod za knjižničare. / priredio I. Chew. Zagreb: Hrvatsko knjižničarsko društvo, 2009.

Statistički podaci i pokazatelji uspješnosti za narodne knjižnice za 2019. godinu. // Portal matične djelatnosti knjižnica u Republici Hrvatskoj, 2019. [citirano: 2020-1228]. Dostupno na: http://maticna.nsk.hr/statistika/preuzimanje.

Vračić, I. Psihološka prva pomoć u krizi. // Koronavirus i mentalno zdravlje: Psihološki aspekti, savjeti i preporuke. / uredila A. Bogdan i suradnici. Zagreb: Hrvatska psihološka komora, 2020. Str. 28-34. [citirano 2020-12-20]. Dostupno na:

http://psiholoska-komora.hr/static/documents/HPK-Koronavirus_i_mentalno_ zdravlje.pdf.

Wiederhold, B. K. Connecting through technology during the Coronavirus disease 2019 Pandemic: Avoiding "Zoom fatigue". // Cyberpsychology, Behavior, and Social Networking 23, 7(2020), str. 437-438. [citirano: 2021-01-25]. Dostupno na: https://www.liebertpub.com/doi/pdfplus/10.1089/cyber.2020.29188.bkw. 